УДК 637.5

\title{
DEVELOPMENT OF PÂTÉ USING THE CHOICE PHYTOCOMPLEX OF CEREAL CULTURES
}

\author{
O. Moskalyuk, A. Haschuk \\ National University of Food Technologies
}

\begin{tabular}{|c|c|}
\hline Key words: & ABSTRACT \\
\hline $\begin{array}{l}\text { Pâté } \\
\text { Health and preventive } \\
\text { nutrition } \\
\text { The CHOICE } \\
\text { phytocomplex of } \\
\text { germinated cereal cultures } \\
\text { Quality indices }\end{array}$ & \multirow{3}{*}{$\begin{array}{l}\text { The article presents the results of the research on the } \\
\text { developed pâté using the CHOICE phytocomplex of cereal } \\
\text { crops (germinated oats, barley, wheat and corn). According } \\
\text { to the organoleptic, physicochemical and functional-techno- } \\
\text { logical indicators, it has been established that the optimum } \\
\text { content of phytocomplex of cereal crops in the pâté formu- } \\
\text { lation is } 15 \% \text {. The results of the study confirm the possi- } \\
\text { bility of using phytocomplex in the production of health and } \\
\text { prophylactic pâté. }\end{array}$} \\
\hline \begin{tabular}{l}
\multicolumn{1}{c}{ Article history: } \\
Received 12.05.2017 \\
Received in revised form \\
25.05 .2017 \\
Accepted 18.06 .2017
\end{tabular} & \\
\hline $\begin{array}{l}\text { Corresponding author: } \\
\text { O. Moskalyuk } \\
\text { E-mail: } \\
\text { npnuht@ukr.net }\end{array}$ & \\
\hline
\end{tabular}

DOI: $10.24263 / 2225-2924-2017-23-4-31$

\section{РОЗРОБЛЕННЯ ПАШТЕТІВ 3 ВИКОРИСТАННЯМ ФІТОКОМПЛЕКСУ ЗЛАКОВИХ КУЛЬТУР «СНОІСЕ»}

\section{O.Є. Москалюк, О.І. Гащук \\ Наџіональний університет харчових технологій}

У статті наведено результати досліджень розроблених паштетів з використанням фітокомплексу злакових культур “СНОІСЕ» (пророщених зерен вівса, ячменю, пшениці та кукурудзи). За органолептичними, фізико-хімічними та функиіонально-технологічними показниками встановлено, щу оптимальний вміст фітокомплексу злакових культур у рецептурі паштету складає (15\%). Результати дослідження підтверджують можливість використання фітокомплексу у виробництві паштетів оздоровчо-профілактичного призначення.

Ключові слова: паштет, оздоровчо-профілактичне харчування, фітокомплекс пророщених злакових культур «СНОІСЕ», показники якості.

Постановка проблеми. Нині актуальним питанням є не тільки випуск високоякісної харчової продукції, але й надання іій функціональних i профілактичних властивостей. Перш за все це пов'язано 3 підвищеною 
потребою організму людини в ессенціальних нутрієнтах і збільшенням захворюваності населення [1].

До функціональних відносяться продукти, які позитивно впливають на здоров'я людини при їх регулярному вживанні в ефективних дозах, що допомагає адаптуватися організму до впливу зовнішнього середовища, запобігати виникненню захворювань і запобігати передчасному старінню [2; 3]. Покращення показників здоров'я можливе тільки за умов дотримання режиму харчування, при якому організм отримує всі необхідні за фізіологічними потребами речовини (вітаміни, макро- та мікроелементи).

Будь-яке тривале відхилення від режиму збалансованого харчування призводить до порушень функцій організму [3-5]. Використання продуктів функціонального призначення в раціонах хворих дає можливість в певній мірі оптимізувати лікувальний процес. Їх доцільно використовувати в харчуванні з метою оптимізації хімічного складу раціону, для загального зміцнення організму людей як молодого, так і літнього віку.

Продукти збалансованого харчування розглядаються не тільки як джерело пластичних речовин і енергії, але і як складний немедикоментозний комплекс, що забезпечує достовірний лікувально-профілактичний ефект. Місце збалансованих продуктів харчування визначається, як проміжне між продуктами загального споживання і продуктами лікувального харчування.

Створення м'ясопродуктів на основі поєднання м'ясної та рослинної сировини $є$ одним з ефективних шляхів вирішення проблеми збалансованого харчування, регулювання властивостей та оптимізації біологічної цінності готового продукту.

Аналіз останніх досліджень і публікацій. У статті Я.В.Курмаза, Л.В. Щербіна, О.М. Бергілевича досліджено розроблені паштети, до складу яких входили пшеничні висівки у кількості від $10 \%$ до $30 \%$. У результаті було досягнуто зменшення калорійності готового продукту, збагачення його харчовими волокнами, вуглеводами, макро- та мікроелементами [6].

Jussi Loponen, Paivi Kanerva, Chonggang Zhang, Tuula Sontag-Strohm (2015 p.), Hannu Salovaara та Michael G. Ganzle (2016 р.) займалися розробленням паштетів з пророщеними зернами пшениці та кукурудзи (15-35\%). Вченими було досліджено хімічний склад, біологічну цінність та функціонально-технологічні властивості паштетів. Результати досліджень показали, що пророщені зерна мають високу водоутримувальну здатність (при вологості продукту $60 \%$ вони здатні зв'язати ще $70 \%$ вологи) і дуже високу жироутримувальну здатність $(90 \%)[7,8]$.

Л.М. Агуновою було досліджено печінкові паштети функціонального призначення, збагачені пророщеною пшеницею та гідробіонтами (ламінарією та фукусами) з частковою заміною тваринних жирів на соєву олію. У результаті досліджень встановлено, що комбінування сировини тваринного і рослинного походження в паштетах дає змогу підвищити їх біологічну ефективність (на $10 \%$ ), збалансувати амінокислотний склад і збагатити продукт вітамінами [9].

Мета дослідження: технологія паштетів, збагачених вітамінами та мінеральними речовинами за рахунок внесення фітокомплексу злакових культур «СНОIСЕ» (пророщених зерен вівса, ячменю, пшениці та кукурудзи). Най- 
більш повноцінними за амінокислотним складом є пророщені зерна кукурудзи, за вітамінним - овес, за мінеральним - ячмінь, що підтверджує доцільність використання злакових культур у складі фітокомплексу.

Виклад основних результатів дослідження. Одним із оптимальних вирішень проблеми оздоровлення харчування $\epsilon$ виробництво паштетів, які часто рекомендують при захворюваннях кишківника, особливо при гастритах. У паштеті містяться інгредієнти тваринного і рослинного походження у легкодоступній для травних ферментів формі. Вибір компонентів рецептури м'ясного паштету обумовлений їх хімічним складом, функціональними і технологічними властивостями та енергетичною цінністю.

Основною сировиною при виробництві паштетів $\epsilon$ : м'ясо куряче, печінка куряча варена, кукурудзяна олія, пшенична клітковина, фітокомплекс «СНОICЕ», сироватка молочна та сухе молоко.

Для визначення показників готових продуктів ми використовували органолептичні, фізико-хімічні методи оцінки якості та методи дослідження функціонально-технологічних показників.

У рецептуру модельних паштетів вносили на стадії фаршескладання фітокомплекс пророслих зерен вівса, ячменю, пшениці та кукурудзи від 5 до 30\%. Як контрольний зразок було взято паштет згідно з патентом на винахід МПК A23L1/317 «Паштет для геродієтичного харчування»).

Рецептури розроблених паштетів представлена у табл. 1.

\section{Таблиия 1. Рецептури розроблених паштетів}

\begin{tabular}{|c|c|c|c|c|c|c|c|}
\hline \multirow{2}{*}{ Найменування сировини } & \multicolumn{7}{|c|}{ Вміст, \% } \\
\cline { 2 - 8 } & Контроль & № 1 & № 2 & № 3 & № 4 & № 5 & № 6 \\
\hline М’ясо куряче & 38,0 & 40,0 & 41,0 & 51,0 & 41,0 & 30,0 & 29,0 \\
\hline Печінка куряча варена & 23,0 & 36,0 & 30,0 & 15,0 & 20,0 & 26,0 & 24,0 \\
\hline Кукурудзяна олія & 5,0 & 5,0 & 5,0 & 5,0 & 5,0 & 5,0 & 5,0 \\
\hline $\begin{array}{c}\text { Пшенична клітковина } \\
\text { гідратована 1:4 }\end{array}$ & 20,0 & - & - & - & - & - & - \\
\hline $\begin{array}{c}\text { Фітокомплекс } \\
\text { пророщених зерен }\end{array}$ & - & 5,0 & 10,0 & 15,0 & 20,0 & 25,0 & 30,0 \\
\hline Молоко сухе & 5,0 & 5,0 & 5,0 & 5,0 & 5,0 & 5,0 & 5,0 \\
\hline Сироватка молочна & 5,0 & 5,0 & 5,0 & 5,0 & 5,0 & 5,0 & 5,0 \\
\hline Цибуля & 2,0 & 2,0 & 2,0 & 2,0 & 2,0 & 2,0 & 2,0 \\
\hline Сіль & 1,99 & 1,99 & 1,99 & 1,99 & 1,99 & 1,99 & 1,99 \\
\hline Перець & 0,01 & 0,01 & 0,01 & 0,01 & 0,01 & 0,01 & 0,01 \\
\hline
\end{tabular}

Показники якості, що визначаються за органолептичною оцінкою (зовнішній вигляд, вид і колір на розрізі, аромат, смак, соковитість) займають одне 3 важливих місць у комплексі показників, що визначають якість харчових продуктів, i їх результати часто бувають вирішальними і кінцевими при розроблені нових виробів. Перевагою цього методу є те, що він відносно швидкий і дає можливість виявити цілий комплекс якостей готового продукту.

Органолептична оцінка модельних паштетів представлена профілограмою (рис. 1).

Найвищу загальну оцінку отримав зразок № 3, в якому вміст фітокомплексу пророщених зерен вівса, ячменю, пшениці та кукурудзи становив 
$15 \%$. Найгірші показники спостерігалися у зразках № 5 та № 6. У цих зразках зовнішній вигляді вигляд на розрізі не відповідали вимогам, вироби не соковиті.

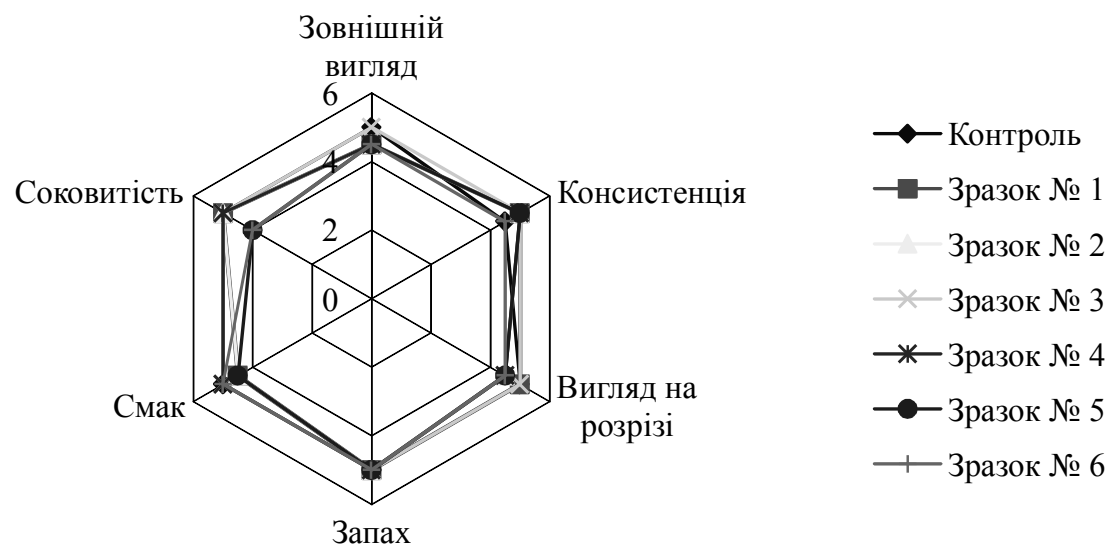

Рис. 1. Органолептична оцінка модельних паштетів

При розробленні паштетів з поєднанням м'ясної і рослинної сировини у заданому співвідношенні важливим є дослідження впливу рослинних компонентів на фізико-хімічні показники готових продуктів. Результати дослідження фізико-хімічних показників паштетів представлено в табл. 2.

\section{Таблицяя 2. Фізико-хімічні показники паштетів}

\begin{tabular}{|c|c|c|c|c|}
\hline \multirow{2}{*}{ Зразок } & \multicolumn{4}{|c|}{ Вміст, \% } \\
\cline { 2 - 5 } & Вологи & Білка & Жиру & Золи \\
\hline Контроль & не більше 70,0 & не менше 12,9 & не більше 15,4 & - \\
\hline Зразок № 1 & $69,0 \pm 0,25$ & $15,9 \pm 0,31$ & $12,9 \pm 0,36$ & $1,90 \pm 0,31$ \\
\hline Зразок № 2 & $69,1 \pm 0,13$ & $15,6 \pm 0,28$ & $12,6 \pm 0,34$ & $2,32 \pm 0,30$ \\
\hline Зразок № 3 & $69,4 \pm 0,18$ & $15,9 \pm 0,30$ & $12,1 \pm 0,30$ & $2,36 \pm 0,28$ \\
\hline Зразок № 4 & $69,2 \pm 0,20$ & $15,1 \pm 0,27$ & $11,8 \pm 0,29$ & $2,30 \pm 0,27$ \\
\hline
\end{tabular}

Результати дослідження показали, що найменший вміст білка має зразок 3 фітокомплексом злакових культур 20\% (зразок № 4) - 15,1\%, проте це значення знаходиться в межах вимог для паштетів згідно з нормативним документом. Найменший вміст жиру в готових паштетах міститься у зразку 3 фітокомплексом злакових культур 15\% та 20\% (зразок № 3 і 4) - 12,1 i 11,8 відповідно.

Вологозв'язувальна та вологоутримувальна здатності фаршу забезпечують створення ніжної, соковитої консистенції готового продукту, збільшення виходу, зменшення втрат при термообробці. Найбільше значення вологоутримувальної та вологозв'язувальної здатності готових паштетів (рис. 2) має зразок з фітокомплексом злакових культур 15\% (зразок № 3) - відповідно $62,7 \%$ та $81,2 \%$. Зразок № 3 також має найбільшу жироутримувальну здатність - 74,6\%, що на 0,3\% більше ніж у контрольному зразку (73,6\%). 


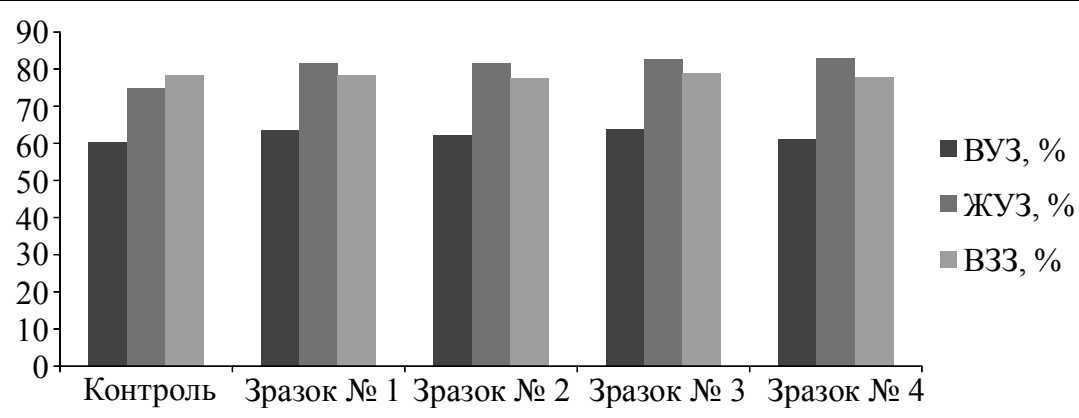

Рис. 2. Функціонально-технологічні показники фаршів модельних зразків і готових паштетів

На діаграмі (рис. 3) представлена динаміка збільшення виходу готових паштетів залежно від кількості внесення фітокомплексу «СНОICЕ».

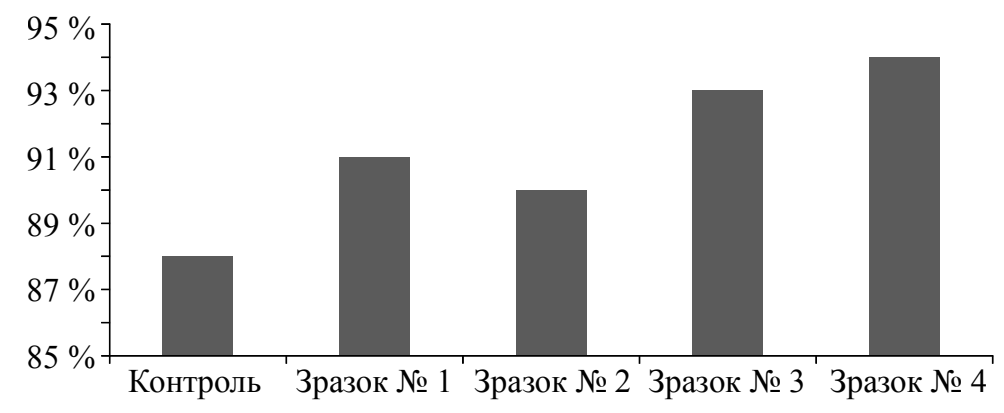

Рис. 3. Вихід готових паштетів

3 діаграми (рис. 3) видно, що збільшення вмісту фітокомплексу злакових культур у рецептурі модельних зразків паштету підвищує вихід на $0,3-0,4 \%$, що свідчить про сумісність обраних компонентів рецептури і їх взаємозв'язок у фарші при технологічних обробках.

\section{Висновки}

Розроблено рецептури експериментальних зразків і проведено дослідження модельних паштетів з використанням фітокомплексу злакових культур «СНОICЕ» (пророщених зерен вівса, ячменю, пшениці та кукурудзи). Результати дослідження підтверджують можливість використання фітокомплексу у виробництві паштетів оздоровчо-профілактичного призначення. За органолептичними, фізико-хімічними та функціонально-технологічними показниками встановлено, що оптимальний вміст фітокомплексу злакових культур у рецептурі паштету складає (15\%).

\section{Лiтература}

1. Микитчук I.I. Використання рослинної сировини про виготовленні м'ясних паштетів/ І.І. Микитчук, Л.Ю. Авдєєва // Наук. вісник ЛНУВМБТ ім. С.З. Гжицького. 2014. —№ 2. — Частина 3. - С. 246-248. 
2. Бутенко Л.И. Исследования химического состава пророщенных семян гречихи, овса, ячменя и пшеницы/ Л.И. Бутенко, Л.В. Лигай // Фундаментальные исследования. 2013. — № 4 (часть 5). - С. 1128-1133.

3. Українець А.I. Технологія оздоровчих харчових продуктів / А.І. Українець, Г.О. Сімахіна // Курс лекцій для студентів за напрямком 6.051701 «Харчові технології та інженерія» денної та заочної форм. Навч. - Київ : Національний університет харчових технологій, 2009. - С. 310.

4. Трубина И.А. Функциональные продукты на мясной основе/ И.А. Трубина // Ежеквартальный научно-практический журнал. - 2012. - № 4(8). - С. 46- 48.

5. Капрельяни Л.В. Селенобагащенные пробиотические продукты функционального назначения/ Л.В. Капрельянц, Н.С. Трегуб // Микробиология и технология. — 2016. № $1 .-$ C. $6-18$.

6. Курмаза Я.В. Обгрунтування використання пшеничних висівок при виробництві функціональних м'ясних продуктів/ Я.В. Курмаза, Л.В. Щербіна, О.М. Бергілевича// Наук. праця ТДАТУ. — 2014. — № 9. - С.125-130.

7. Jussi Loponen. Enzymes of sprouted wheat and their possible technological significance/ Paivi Kanerva, Chonggang Zhang, Tuula Sontag-Strohm // Chapman\&Hall. — 2015. P. 143-144.

8. Hannu Salovaara Growth features of PbS crystals grown in silica gels / Hannu Salovaara, Michael G. Ganzle // Journal of Crystal Growth. — 2016. — № 6. - 282-288.

9. Віннікова Л.Г. Вплив внесення нетрадиційної сировини на тривалість зберігання м'ясопродуктів функціонального призначення/ Л.Г. Віннікова, Л.В.Агунова, Н.Г. Азарова // Наукові праці ОНАХТ. - 2009. - С. 104-108. 